\title{
Meta
}

Journal des traducteurs

Translators' Journal

\section{HoUSE, Juliane, ed. (2014): Translation: A Multidisciplinary Approach. Basingstoke: Palgrave Macmillan, 290 p.}

\section{Mario Bisiada}

Volume 60, numéro 3, décembre 2015

URI : https://id.erudit.org/iderudit/1036148ar

DOI : https://doi.org/10.7202/1036148ar

Aller au sommaire du numéro

Éditeur(s)

Les Presses de l’Université de Montréal

ISSN

0026-0452 (imprimé)

1492-1421 (numérique)

Découvrir la revue

Citer ce compte rendu

Bisiada, M. (2015). Compte rendu de [House, Juliane, ed. (2014): Translation: A Multidisciplinary Approach. Basingstoke: Palgrave Macmillan, 290 p.] Meta,

60(3), 640-644. https://doi.org/10.7202/1036148ar

Ce document est protégé par la loi sur le droit d'auteur. L'utilisation des services d'Érudit (y compris la reproduction) est assujettie à sa politique d'utilisation que vous pouvez consulter en ligne.

https://apropos.erudit.org/fr/usagers/politique-dutilisation/
Cet article est diffusé et préservé par Érudit.

Érudit est un consortium interuniversitaire sans but lucratif composé de l'Université de Montréal, l'Université Laval et l'Université du Québec à Montréal. Il a pour mission la promotion et la valorisation de la recherche. https://www.erudit.org/fr/ 
Dutch, indicates that the discourse-related function of the imperatival forms of the particles is not restrained by their traditional label as attentiongetting devices. This finding is followed by a crosslinguistic comparison of the pragmatic markers (resulting from the imperative 'look') in three Romance languages with look and kijk in order to investigate the sequence of changes they underwent in the course of their evolution from the imperative to pragmatic markers. Similar to Beeching's, the question of grammaticalization is addressed in Van Olmen's article. However, here the author calls into question the most predominant views on whether or not the emergence of the imperative of intentional visual perception as a pragmatic marker follows any path of grammaticalization and claims that existing debates are purely ideological and not capable of providing very informative clues in this regard. The paper is particularly significant as, contrary to Romance languages, there exists a limited number of studies concerning the use of the imperative of intentional visual perception as a pragmatic marker on Germanic languages.

Fagard, in É vida, olha...: Imperatives as discourse markers and grammaticalization paths in Romance: A diachronic corpus study examines Spanish and Catalan mira, Portuguese olha, Italian guarda, French regarde, and Romanian uite regarding the usage and the degree of grammaticalization. The data is obtained from Valibel, PFC, and Clapi corpora for French, CREA and CCCUB respectively for Spanish and Catalan, CORV and Ruxandoiu for Romanian, LIP for Italian, and Corpus do Português for Portuguese. The author tests each particle for a set of discourse functions and concludes that the uses of French regarde as a discourse marker is of lower rate in comparison to those of other particles. Furthermore, the results of the paper reveal that the discourse-related functions of all Romance items seem to originate from a grammaticalization process; however, the term regarde demonstrates a lesser degree of grammaticalization which is at odds with the recent findings subscribing to the idea that French, among Romance languages, is the most grammaticalized one. In the conclusion of his paper, Fagard explains this inconsistency by setting forth a number of hypotheses. For example, the author hypothesizes that there might be some exceptions to the general trend in the evolution of Romance languages.

On the whole, the transparent structure and the clear language of the articles along with their originality make the book an asset to every scholar and graduate student interested in the field of pragmatic markers and contrastive studies. Besides, the cross-linguistic contrastive approach towards cognate forms, which clarifies their similarities and differences in terms of semantics and pragmatic functions, would bear constructive consequences for teaching as well as translation practices.

Esmaeil Kalantari

Université de Montréal, Montreal, Canada

\section{REFERENCES}

Aijmer, Karin, Foolen, Ada and Simon-VandenBergen, Anne-Marie (2006): "Pragmatic markers in translation: a methodological proposal." In: Kerstin Fischer, ed. Approaches to discourse particles, 101-114.

Chamizo Domínguez, Pedro J. and Nerlich, Brigitte (2002): False friends: their origin and semantics in some selected languages. Journal of Pragmatics, 34(12):1833-1849.

CuencA, Maria-Josep (2008): Pragmatic markers in contrast: The case of $<\mathrm{i}>$ well $</ \mathrm{i}>$. Journal of Pragmatics, 40(8):1373-1391.

Launers, Peter and Vermote, Timothé (2014): La flexibilité de l'opposition massif/comptable en français et en néerlandais: une étude contrastive. Syntaxe et Sémantique, 15:139-170.

Tseronis, Assimakis (2009): Qualifying standpoints. Stance adverbs as a presentational device for managing the burden of proof. Utrecht: LOT, Netherlands Graduate School of Linguistics.

VAnderbauwhede, Gudrun (2012): The integrated contrastive model evaluated: the French and Dutch demonstrative determiner in L1 and L2. International Journal of Applied Linguistics, 22(3):392-413.

Vanderbauwhede, Gudrun and Verleyen Stijn (2010): "The French and Dutch noun phrase in contrast.” In: Lahousse, Karen, Lamiroy, Béatrice and Van Goethem, Kristel, dirs. French Syntax in Contrast. Special Issue of Lingvistica Investigationes, 33(2):267-284.

House, Juliane, ed. (2014): Translation: A Multidisciplinary Approach. Basingstoke: Palgrave Macmillan, 290 p.

What makes translation studies an interesting field in which to do research is its interdisciplinarity. While this interdisciplinarity is argued by some to be inherent in the field (Snell-Hornby 1988), there have been continuous attempts to give translation studies its own research methodologies (Baker 2009: 279). Translation: A Multidisciplinary Approach goes a long way towards that by presenting approaches and viewpoints from neighbouring disciplines that scholars have used to conduct research into translation. The authors present insights that such research has recently yielded and suggest possibilities for future work, making it an excellent starting point both for researchers in search of new ideas for projects and students embarking on a translation degree. 
There have been many attempts to define translation, variously using key concepts such as equivalence or semiotics as bases (see Schjoldager, Gottlieb et al. 2008: 17; Boase-Beier 2011: 3). In the present volume, translation is defined as "the result of a linguistic-textual operation in which a text in one language is re-produced in another language" (p. 1). That linguistic-textual operation is said to be "subject to, and substantially influenced by, a variety of different extra-linguistic factors and conditions" (p. 1). The complexity of the field of translation studies is argued to stem from this interplay of "linguistic-textual" and "extra-linguistic contextual" factors, all of which provide "starting point $[\mathrm{s}]$ for investigating translation" (p. 2).

Thankfully, the book does not participate in what is sometimes called the "cultural turn" in translation studies, whose adherents seek to disassociate the field from linguistics and strive to avoid linguistic approaches altogether (see, for example, Bassnett and Lefevere 1990). The stated aim of the present volume is to "provide the reader with exciting new perspectives on translation, an increasingly important field in applied linguistics," "setting the scene for further advancement in translation studies as a multidisciplinary field of research and practice" (p. 13). Given that the volume is likely to establish itself as a major work of reference, it is refreshing to see that it contributes to Baker's call for translation studies to "draw on a variety of discourses and disciplines and to encourage pluralism and heterogeneity" (Baker 2009: 280).

The introduction by Juliane House starts out in this spirit by discussing translation as a linguistic act, as intercultural communication, as a social act in context and as a cognitive process. House then gives a detailed summary of each chapter, which goes beyond the usual one-sentence outline and allows readers to get an idea of the content of each chapter and read those of interest to them.

The chapters are organised into two blocks. The first block, consisting of chapters 2 to 7 , "tackles issues of general theoretical relevance to the entire field of translation studies" (p. 8). The second block, consisting of chapters 8 to 13 , "addresses the role of translation in specific domains and genres" (p. 8).

In the first chapter, Translation and Equivalence, Monika Krein-Kühle discusses the controversy surrounding the issue of equivalence in translation studies and criticises "the ideology that has pushed the concepts of translation and equivalence from the centre to the periphery" (p. 32). She makes a case for more careful, corpusbased research into the issue of equivalence in translation.
The second chapter in the block, Discourse and Translation - A Social Perspective by Ian Mason, argues for translation to be viewed as a socially situated activity. Mason proposes adopting the framework of communities of practice to study discourse and translation and argues that the micro-analysis of translation events can contribute evidence of translator decision-making.

The next chapter is entitled Chinese Discourse on Translation as Intercultural Communication: The Story of "jihe." Highlighting translation as a locus of contact between cultures, its author, Martha Cheung, tells the story of the Chinese word jihe as the translation of the English word geometry. She argues that dichotomous concepts such as domestication/foreignisation are often not adequate to describe the interaction in translation.

Marie-Noëlle Guillot's chapter Cross-Cultural Pragmatics and Translation: The Case of Museum Texts as Interlingual Representation is concerned with cross-cultural pragmatics in the example of museum texts. Guillot reports on a study of students' responses to museum texts from various countries that they have translated. Her work raises questions on whether texts should be adapted to communicative conventions of the target language or whether the original style should be allowed to shine through.

In the following chapter, Svenja Kranich discusses Translation as a Locus of Language Contact. She provides an overview of some existing research on the question of whether features of the source language in translation can spread to monolingual text production. Her chapter reviews some hypotheses about language contact in translation in an attempt to shed more light on how specific features of the translation situation shape the outcome of language contact in translation.

The final chapter in this first block is called Reorienting Translation Studies: Cognitive Approaches and the Centrality of the Translator by Sandra L. Halverson. As the title suggests, Halverson argues for a more central role of the translator in translation studies. Cognitive approaches to translation are proposed as ways to overcome existing criticisms of linguistic approaches to translation.

The second block, discussing specific domains of translation, begins with the chapter Literary Translation by Cees Koster. The author offers an overview of issues involved in literary translation and some angles from which it can be studied. Koster discusses, among other things, literary translation as a social and cultural phenomenon and style as a technical translation problem.

Chapter 9 is entitled Translation as Renarration. Written by Mona Baker, it deals with the application of narrative theory to translation studies. Conceptual tools for the analysis of trans- 
lation and interpreting events are discussed and exemplified. Baker then applies narrative analysis to a political commercial in a small case study that shows how translation is used to give a sense of reportedness and objectiveness to a fictional text.

The next chapter's author, Federico Zanettin, provides an overview of Corpora in Translation. Starting with an account of how corpus linguistics was adopted by translation scholars, his chapter discusses the use of corpora both in translation research and translation practice. He then presents some possibilities for future research.

In the following chapter, entitled Translation and New(s) Media: Participatory Subtitling Practices in Networked Mediascapes, Luis PérezGonzález discusses amateur translation in the changing landscape of news media and how cocreational practices and self-mediation turn the passive, information-consuming citizen into an active one that contributes to the ongoing political discussions.

The twelfth chapter in the volume, The Role of Translation in Language Learning and Teaching by H. G. Widdowson, argues against the widespread assumption that the language learners' L1 should be kept out of the classroom. Widdowson instead proposes crediting the achievement of meaningmaking in language learning by drawing on all the learners' linguistic resources.

In the final chapter, Juliane House revisits proposals on the judgement of translation quality (Translation Quality Assessment: Past and Present). She provides an overview of existing approaches to the issue and suggests some ways to assess translation quality based on a combination of product-oriented and process-oriented studies.

The volume provides an excellent introduction to translation studies and its surrounding issues by emphasising its interdisciplinarity. While the editor names the targeted readership as "researchers and practicing translators" (p. 13), it seems to me that undergraduate students can also benefit from this book. This would be true especially for the domain-specific overviews in the second block. While some chapters are probably too difficult for the undergraduate level, others certainly seem suitable as introductory texts to the specific research field (for instance, chapters 2, 9 and 10).

Due to the aforementioned interdisciplinarity of translation studies as a field, the chapters in this volume draw on a large variety of disciplines, making the coherence of the book a difficult editorial task, which has, however, been well-managed. Coherence is achieved by the fact that authors, at least in the first block of chapters, cross-reference to other chapters.

The book is at its best when its authors try to stimulate necessary debates in the field. One example here is Krein-Kühle's chapter, where the author argues that scholars in the field have lost sight of "the central object of study" (p. 32), namely the relationship between the source text and the target text. Accounting for the nature, conditions and constraints defining equivalence, she claims, "remains a central task of our discipline" (p. 17), and should be pursued by conducting "empirical research into carefully selected, theoretically well-framed, contextualised and, optimally, highquality translation corpora" (p. 31).

The numerous approaches that this volume draws on makes it almost impossible, in a review written by one person, to give credit to all the contributions that this work will make to the discipline. Therefore, I will expand on only two chapters that I found particularly interesting and enlightening. Needless to say that this choice reflects mainly personal preference rather than any judgement of the quality of the other chapters.

The use of translation in the language classroom has recently been a matter of debate, a topic to which H. G. Widdowson contributes an excellent and radical proposal to reject the "traditional doctrine of monolingual teaching” (p. 237). Instead, we should encourage language students to develop the ability to use language through translating. However, Widdowson does not refer to translation in the usual definition (and, for that matter, the one adopted in this volume; see above). He criticises definitions of translation that restrict the activity to one where a text is the outcome. He argues that translating is something that we all do when we interpret and reformulate things others say, even in our own language, but which does not necessarily lead to a text product. Based on this point, he differentiates translators, whose specialist task is to produce such a text, from translaters, which includes every language user, so that translation is a "process of making meaning into and out of text” (p. 229).

The purpose of language teaching, then, should be to teach learners how to be language users, or translaters, in another language. However, as the received wisdom is that any reference to the learners' L1, including translation, interferes with successful teaching, Widdowson sees "a fundamental conflict between the continuous process of bilingual or multilingual learning and the discontinuous practice of monolingual teaching" (p. 229). What gets a bit lost here is that, defining translation the way Widdowson does, I would guess that few language teachers would argue that it has no place in the language class.

Language teaching is seen as teaching a language, he writes, a separate entity to the learners' L1, when it should really be seen as teaching language, i.e., "the extension of an existing linguistic 
resource" (p. 230). Learners, he argues, are forced into the unnatural situation of using only the L2 and are then measured in terms of native speaker norms. He considers task-based language teaching to be teacher-oriented rather than learneroriented, where the only learning that counts is "that which conforms to what is pedagogically prescribed” (p. 235).

Nevertheless, learning a foreign language in a country where that language is not spoken seems, by definition, unnatural. The most natural thing to do in a class of, say, Spanish native speakers would be to speak Spanish, not the language they are learning. The question is, therefore: how to create classroom tasks that maintain a natural scenario of language use? That is, how can we design a task in which, as Widdowson demands, learners make use of all the linguistic resources at their disposal, if at the same time we want to prevent them from using just their L1? The best situation would obviously be an international classroom where speakers do not share an L1 and thus have to use the L2 as a common lingua franca, even if they cannot speak it adequately yet. While this might be possible in, say, an English course in London for refugees from all over the world who do not share a native language, it is hard to achieve in the homogeneous teaching environment that most of us encounter.

Widdowson offers only a small selection of proposals on this issue. He suggests for teachers to encourage learners to translate, to "teach the properties of language in general as a means of conceptualisation and communication which are variously realised through different languages" (p. 236). He argues that a truly learner-centred pedagogy would encourage learners to recognise how meaning can be made alternatively using other languages. Most controversially, credit would be given to the achievement of making meaning, "no matter what non-conformist or linguistically hybrid form this takes" (p. 237). While his main idea merits discussion and will hopefully draw a lot of response from other scholars, some suggestions, such as designing particular syllabuses depending on the learners' L1, have already been put to successful use in language schools and books.

The second chapter I would like to expand on is Svenja Kranich's chapter about language contact in translation and her suggestions for future directions in this matter. I have investigated this particular issue in my own work, as I have replicated research conducted in the Covert Translation product (specifically Becher 2011) by studying diachronic variation in hypotaxis and parataxis, but in the business article genre (Bisiada 2013a). As the magazine I drew my corpus from had only just been founded at the first time period in which I collected data (1982), the business genre is arguably not as established as popular science. I found that hypotaxis was not declining as strongly as in the popular science articles (Bisiada 2013a: 22-23), which might argue against the idea that lesser established genres are more likely to be influenced by source language patterns, one of the hypotheses considered by Kranich (p. 106).

The role of translation in language variation and change is still contested and more work, also on the theoretical level, is needed. While Kranich talks about "syntactic innovations in the TL" (p. 108) and of phenomena that "might spread to monolingual text production," I am not sure whether translators really can be innovators, except on the lexical level. From a syntactic point of view, it seems much more likely that language contact in translation can lead to frequency shifts in the use of given constructions or patterns (see also Bisiada 2013b: 27-28). In any case, we never know for sure what the strongest influences on the language user are. That is also why I am not sure whether language contact in the translation of ancient languages can be readily compared to the translation of modern languages, as Kranich does (p. 101). Most significantly, phenomena observed in ancient languages can more acceptably be called issues of language change, while in modern languages we can only observe variation or at best change in progress. For ancient languages, we do not know if the documented language use represents general use. Therefore, I would be dubious as to whether the hypotheses suggested by Kranich in this chapter can really be judged on the basis of the analysis of, say, contact in translation from Latin to Old Swedish (p. 108).

While the volume on the whole achieves a good balance of subfields, some readers may lament the absence of a chapter dedicated to machine translation. While the working definition of translation used in the book (see above) does not explicitly limit the term to humans, machine translation is only discussed in a subsection of Zanettin's chapter on corpora in translation (p. 190-192). That chapter is already somewhat packed with information so that it can only provide a cursory overview of the different topics of translation that corpus-based research has informed. Perhaps a separate chapter on the use of corpora in translation practice would have given corpus applications the credit that they deserve in the field of translation studies.

Overall, the book is well-edited and proofread, with typographical errors kept to a minimum and a negligible amount of structural issues. Section 10.2 would have benefitted from some subsections. Occasionally, paragraphs are too long (p. 22-23, 77-78, 79, 149-150), adding unnecessary difficulty to the complexity of the topics (one 
almost two page-long paragraph from page 18 to 20 stands out). At times, what are presented as back translations are somewhat confusing for the reader due to their ungrammaticality, seeming to randomly reflect some structural features of the source language but not others ("With the in this special report investigated capture and storage [...]," p. 29; "[...] and him enables to procure some meat fresh [...]," p. 82). As no commonly accepted standards for interlinear/gloss translations exist, these examples could have been made more accessible by a conventional gloss as standard in linguistics or a grammatical translation, especially as word order does not seem particularly relevant to the arguments made here.

A negative point about the paperback version of this book, especially given the reputation of its publisher, is that the inside margins are so small that the book cannot be read comfortably without forcing it apart at the spine or pressing it flat. This is a drawback especially for an academic book which often needs to be placed on a table and referred to while writing or typing rather than being held continuously.

In sum, however, the great achievement of the volume is that it provides an overview of translation studies and the various disciplines with which it interacts, as well as the angles from which it can be approached, making this book a treasure trove for researchers and students embarking on projects in the field.

MARIO BISIADA Universitat Pompeu Fabra, Barcelona, Spain

\section{REFERENCES}

BAKer, Mona (2009): Translation studies. In: Mona BAKER and Gabriela SAldANHA, eds. Routledge Encyclopedia of Translation Studies. London: Routledge, 277-280.

Bassnett, Susan and Lefevere, André (1990): Translation, History and Culture. London: Pinter Publishers.

Becher, Viktor (2011): Von der Hypotaxe zur Parataxe: Ein Wandel im Ausdruck von Konzessivität in neueren populärwissenschaftlichen Texten. In: Eva Breindl, Gisella Ferraresi and Anna Volodina, eds. Satzverknüpfungen. Zur Interaktion von Form, Bedeutung und Diskursfunktion. Berlin: de Gruyter, 277-280.

BISIADA, Mario (2013a): Changing conventions in German causal clause complexes: A diachronic corpus study of translated and non-translated business articles. Languages in contrast 13(1):127.

BisiadA, Mario (2013b): From Hypotaxis to Parataxis: An Investigation of English-German Syntactic Convergence in Translation. Doctoral thesis, unpublished. Manchester: University of Manchester.
BoAse-BeIER, Jean (2011): A Critical Introduction to Translation Studies. London: Continuum.

Schjoldager, Anne, Gottlieb, Henrik and KlitGARD, Ida (2008): Understanding Translation. Aarhus: Academica.

Snell-Hornby, Mary (1988): Translation Studies: An Integrated Approach. Amsterdam: John Benjamins.

Králová, Jana y Cuenca Drouhard, Miguel José (2013): Jiř́i Levý: una concepción (re)descubierta. Soria: Diputación Provincial de Soria, $179 \mathrm{p}$.

Cincuenta años después de la publicación de la obra clave del filólogo checo Jiří Levý (1926-1967), Umění překladu [El arte de la traducción] (1963), aparece una antología española que brinda al mundo académico hispanohablante la oportunidad de conocer las ideas y concepciones fundamentales de este teórico checo de la traducción. Las aportaciones procedentes del ámbito eslavo, el checo incluido, quedan ignoradas o poco descubiertas en la traductología internacional; en efecto, Levý optó por utilizar su lengua materna para formular sus tesis principales, ahí radica seguramente el desconocimiento de sus trabajos. Los profesores Jana Králová y Miguel José Cuenca Drouhard, de la Univerzita Karlova v Praze [Universidad Carolina de Praga], han sabido recopilar cuidadosamente los textos más representativos y esenciales de Levý y verterlos al español. Asimismo, cabe destacar el prólogo de Miguel Ángel Vega Cernuda que caracteriza el pensamiento de Levý como uno de los pensamientos más originales de la traducción.

El libro consta de una introducción y cinco capítulos. La introducción pone de manifiesto las raíces metodológicas del autor que parten del Círculo Lingüístico de Praga y respeta el orden de la primera aparición de sus trabajos. Entre las contribuciones de Levý destacan, ante todo, los dos siguientes postulados: la atención a la perspectiva histórica de la traducción y la consideración del ejercicio de la traducción como elemento integrante del sistema literario de una lengua. Asimismo, Levý se fija en la figura del traductor que no deja de evolucionar y constituye el elemento activo del proceso de la traducción.

El primer capítulo ofrece al lector español el prólogo a la primera edición y el epílogo de České teorie prekladu [Teorías checas de la traducción] (1956) que ponen énfasis en la especificidad de la evolución de la traducción checa, vinculada estrechamente a las necesidades inmediatas de la vida nacional, exigencias de carácter, ante todo, estético e ideológico. La cuestión estética gira en torno al novedoso "sistema de opiniones estéticas" 